\title{
FAILURE OF HYSTERECTOMY TO AFFECT THE OVARIAN CYCLE OF THE MARSUPIAL TRICHOSURUS VULPECULA
}

\author{
MEREDITH J. CLARK AND G. B. SHARMAN \\ CSIRO, Division of Wildlife Research, Canberra, Australia
}

(Received 10th Fuly 1965)

\begin{abstract}
Summary. Eight females were hysterectomized, three at 5 days, three at 10 days and two at 15 days after oestrus. Seven returned to oestrus at the expected times, 24 to 32 days after the preceding oestrus, and four of these had a subsequent oestrous cycle of normal length. The corpus luteum of hysterectomized animals killed at various stages of the first and second post-operative cycles was compared with that of control non-operated animals killed at similar stages of the cycle and no differences were found. It is concluded that hysterectomy was without effect on the ovarian cycle of the brush possum.
\end{abstract}

The effects of hysterectomy on the ovarian cycle have been studied in a number of mammalian species. A recent summary of inter-specific differences was given by Perry \& Rowlands (1961) who stated that reactions to hysterectomy had been studied in fourteen mammalian species, including one marsupial, the American opossum (Didelphis).

Mature brush possums (Trichosurus vulpecula Kerr) were collected at the beginning of the breeding season and vaginal smears were taken daily until oestrus was detected. Methods of taking vaginal smears, handling and feeding were as given by Pilton \& Sharman (1962). The animals were anaesthetized with Sodium Amytal (Eli Lilly and Co.) given by intraperitoneal injection at a dose of $85 \mathrm{mg} / \mathrm{kg}$ of body weight. The Fallopian tubes and the distal ends of both uteri were ligated and the material between the ligatures was removed. This resulted in removal of the entire uterus, with the exception of the uterine papilla which projected caudally into the anterior vaginal sinus. This uterine remnant, which remained after operation, was examined at autopsy and found to consist of a cone of tissue, less than $5 \mathrm{~mm}$ long, pierced by the os uterus and devoid of the characteristic glandular tissue of the uterine body.

Oestrous cycle lengths in hysterectomized and non-operated control animals are given in Table 1. Hysterectomized animals had both shorter and longer cycles than did controls and no significant difference between cycle lengths was established. The higher mean figure for hysterectomized animals was largely due to one abnormally long cycle of 38 days. Pilton \& Sharman (1962) reported 
cycle lengths ranging from 22 to 32 days with a mean of $25.69 \pm 0.31$ days in the brush possum. This is shorter than, but not significantly different from, the cycle length of hysterectomized animals. The gestation period of the brush possum is 17.5 days and two animals were, respectively, 5 and 10 days pregnant when hysterectomized. They returned to oestrus 27 and 25 days after the oestrus at which fertilization occurred. One animal, hysterectomized at 15 days, did not apparently return to oestrus for a long period after operation but when killed was found to have an old corpus luteum formed since hysterectomy. Ovulation, and presumably oestrus, had thus occurred after the operation but had not been detected. Since the cycle length could not be determined this animal could not be included in Table 1 .

TABLE 1

OESTROUS GYCLE LENGTHS IN HYSTEREGTOMIZED AND CONTROL FEMALES of Trichosurus vulpecula

\begin{tabular}{|c|c|c|c|c|}
\hline \multirow{2}{*}{$\begin{array}{c}\text { Day operated } \\
\text { (days after oestrus) }\end{array}$} & \multirow{2}{*}{$\begin{array}{c}\text { No. of } \\
\text { animals }\end{array}$} & \multicolumn{3}{|c|}{ Length of oestrous cycles (days) } \\
\hline & & 1 & 2 & Mean \pm s.e. \\
\hline $\begin{array}{r}5 \\
10 \\
15\end{array}$ & $\begin{array}{l}3 \\
3 \\
1\end{array}$ & $\begin{array}{l}24^{*}, 27 \dagger, 27 \\
25 \ddagger, 29,30 \\
32\end{array}$ & $23, \begin{array}{l}27 \\
27\end{array}, 38$ & $27 \cdot 9 \pm 1 \cdot 2$ \\
\hline Control & 4 & $24,25,26,29$ & - & $26 \cdot 0 \pm 1 \cdot 1$ \\
\hline
\end{tabular}

* Killed when first returned to oestrus.

+ Pregnant at hysterectomy, killed 15 days after first return to oestrus.

f Pregnant at hysterectomy.

One animal was killed at its first return to oestrus and four were killed at their second oestrus after operation. In the brush possum the corpora lutea degenerated slowly and that of the preceding ovulation was of macroscopic size and easily detected at oestrus, when it was about 25 days old (Pilton \& Sharman, 1962). The old corpora lutea of the five experimental animals killed at oestrus closely resembled in size and state of cells the old corpora lutea of non-operated animals at oestrus. One animal was killed 15 days after its first post-operative oestrus and one 15 days after its second post-operative oestrus. Their corpora lutea were in every way like those of non-operated animals 15 days after oestrus.

It was concluded that hysterectomy is without significant effect on the oestrous cycle and that the brush possum resembles, in this respect, the American opossum (Hartman, 1925), the ferret (Deanesly \& Parkes, 1933) and the macaque (Burford \& Diddle, 1936).

We are indebted to Mr J. C. Merchant and to Mr L. J. Roux for assistance with animal handling, surgery and the taking and interpretation of vaginal smears. 


\section{REFERENCES}

Burford, T. H. \& Diddle, A. W. (1936) Effect of total hysterectomy upon the ovary of the Macacus rhesus. Surg. Gynec. Obstet. 62, 701 .

Deanesly, R. \& Parkfs, A. S. (1933). The effect of hysterectomy on the oestrous cycle of the ferret. F. Physiol., Lond. 78, 80.

Hartman, C. G. (1925) Hysterectomy and the oestrous cycle in the opossum. Am. F. Anat. 35, 25.

Perry, J. \& Rowlands, I. W. (1961) Effect of hysterectomy on the ovarian cycle of the rat. F. Reprod. Fertil. 2, 332.

Pilton, P. E. \& Sharman, G. B. (1962) Reproduction in the marsupial Trichosurus vulpecula. F. Endocr. $25,119$. 